\title{
STUDIES ON GLUCOSE-LOWERING EFFICACY OF THE ACACIA SUMA ROXB. ROOT
}

\author{
JITENDRA DEBATA ${ }^{1 *}$, SUNDEEP KUMAR HK ${ }^{2}$
}

${ }^{1}$ Department of Pharmaceutical chemistry, GNITC-School of Pharmacy, Ibrahimpatnam, Rangareddy, Telangana, India. ${ }^{2}$ Department of Pharmaceutical chemistry, Institute of Pharmacy and Technology, Salipur, Cuttack, Odisha, India. Email: jitendra_debata@rediffmail.com

Received: 30 April 2019; Revised and Accepted: 28 June 2019

ABSTRACT

Objective: The objective of the study was to evaluate the glucose-lowering efficacy of the Acacia suma Roxb. (Family: Fabaceae) root extracts on Wister albino rats.

Methods: A. suma roots were shade dried, powdered, and extracted by Soxhlet extraction procedure using petroleum ether, chloroform, ethanol, and water. The acute toxicity studies were conducted on Swiss albino mice as per the OECD guidelines 423 . The antidiabetic activity of extracts was evaluated on adult Wistar rats at dose levels of 100,200, and $400 \mathrm{mg} / \mathrm{kg}$ P.0, respectively each using normoglycemic,glucose-loaded and Streptozotocin-induced rats. Metformin $(50 \mathrm{mg} / \mathrm{kg}$ ) was used as a reference standard for activity comparison.

Results: Among the tested extracts, the ethanol extract was found to produce promising results that are comparable to that of the reference standard metformin.

Conclusion: The study established the scientific basis for the utility of this plant in the treatment of diabetes and justifies the use of the root of the plant for treating diabetes as suggested in folklore remedies.

Keywords: Acacia suma, Streptozotocin, Metformin, Hyperglycemic, Normoglycemic, Oral glucose tolerance test.

(C) 2019 The Authors. Published by Innovare Academic Sciences Pvt Ltd. This is an open access article under the CC BY license (http://creativecommons. org/licenses/by/4. 0/) DOI: http://dx.doi.org/10.22159/ajpcr.2019.v12i8.33787

\section{INTRODUCTION}

Diabetes mellitus (DM) is the most common endocrine disorder in women and men, and the major health problem of the public becomes epidemic proportion [1], once upon a time believed to be diseased of the west, now is becoming endemic to urbanizing and modernizing population in our country [2]. Ayurvedic literature reveals that different oral preparations used to cure DM (madhumeha) were obtained from herbal medicines. Their claims of cure were recorded [3]. During the past decade, globally traditional systems of medicines have become an important topic [4]. Acacia suma (Roxb.) syn. Acacia polyacantha (Family Fabaceae) is a medium-sized deciduous tree; trunk with fissured bark and knobby persistent prickles widely distributed in India and coastal districts of Odisha $[5,6]$. The roots and leaves of $A$. suma were used as antimalarial, antifungal, insecticide, aphrodisiac, antivenin, and anticrustacean and also used in the treatment of asthma, sores, and abscesses [7-13]. The seeds are reported to have a hypoglycemic effect [14]. The bark is reported to be used as a blood purifier [6] and possesses anticancer, molluscicidal, insecticide, and astringent properties [14-16]. The hypoglycemic activities of different extracts of bark are reported by the authors [17]. The presence of proanthocyanidin [14], 5,4'-dihydroxy-7, 3'-dimethoxyflavone-3-0-D galactopyranoside $[15,18]$, gallocatechin-5-7-digallate, quercetin, and gallocatechin-7 gallate [16] in the barks has been reported earlier. Root suspension of $A$. suma used by the tribes of the Ganjam district of Odisha to reduce the blood sugar in the patients with DM, and they claim for its promising activity. In the light of the above importance of this medicinal plant, the present investigation was to establish scientific support for the said folklore claim.

\section{MATERIALS AND METHODS}

\section{Plant Materials}

Intact root pieces were collected during June 2017 carefully from experimental plants inhabiting in forests of the Ganjam district of
Odisha, India, and authenticated by taxonomists of the Botanical Survey of India, Shibpur, Howrah, West Bengal, India. A voucher specimen was kept in our laboratory for future reference. After authentication, fresh roots were collected in bulk, washed with normal water to remove adhering dirt followed by rinsing with distilled water, and were then dried under a shade and powdered.

\section{Preparation of the extract}

The dried and powdered root $(600 \mathrm{~g})$ first defatting with petroleum ether $\left(60-80^{\circ} \mathrm{C}\right)$ for $48 \mathrm{~h}$ was successively extracted with chloroform, ethanol, and water for $48 \mathrm{~h}$ in a Soxhlet extractor. Following extraction, the liquid extracts were concentrated under reduced pressure to yield dry residues. The percentage yield was calculated to the dried plant material (yield: $6.4 \% \mathrm{w} / \mathrm{w}$ ).

\section{Preparation of the test samples}

The measured quantity of petroleum ether, chloroform, ethanol, and water extracts of the root of $A$. suma and metformin $(150 \mathrm{mg} / \mathrm{kg})$ was suspended in $20 \%$ Tween 20 in distilled water and used as a test drug for oral administration.

\section{Maintenance of animals and approval of the protocol}

Healthy albino Wistar rats of either sex weighing 150-200 g body weight were collected from the institutional animal house for the study. The selected animals were housed in polypropylene cages in standard environmental conditions (temp: $20-25^{\circ} \mathrm{C}$; relative humidity: $45-55 \%$ under $12 \mathrm{~h}$ light/dark cycle) and fed with standard rodent diet for 1 week to adapt to the laboratory conditions and water ad libitum. All experimental protocols were approved by the Institutional Animal Ethics Committee of the Institute of Pharmacy and Technology (Regd. No. 1053/PO/Re/S/07/CPCSEA).

\section{Acute toxicity study}

The acute toxicity studies were conducted on Swiss albino mice as per the OECD guidelines 423 [19], where the maximum test dose 
limit of $2000 \mathrm{mg} / \mathrm{kg}$, p.o., was used. The methods of Ganapaty et al. [20] and Shivhare et al. were followed [21]. Immediately after dosing, the animals were closely observed for the initial $4 \mathrm{~h}$ after the administration and then once daily during the following days. The behavioral changes of animals were closely observed for hyperactivity, ataxia, convulsion, salivation, tremors, and sleep. The animals were kept under observation for 14 days after drug administration to determine the mortality if any. Onetwentieth, onetenth, and onefifth of the maximum tolerated dose $(100,200$, and $400 \mathrm{mg} / \mathrm{kg}$, body weight, p.o.) of the different extracts of $A$. suma were selected for antidiabetic studies.

\section{Determination of blood glucose levels}

Standardized blood glucose meter was used to measure fasting blood glucose. Blood samples were collected from the tip of the tail at the regular time intervals under mild anesthesia.

\section{Using normoglycemic rats}

The method of Acharyya et al., 2010, was followed [17]. The animals were fasted for $18 \mathrm{~h}$ but were allowed free access to water before and throughout the experiment. Time is taken as $(0 \mathrm{~h})$ zero time when the fasting period ended. The normal rats were then divided into fourteen groups of six animals in each group. Group I animals (solvent control) were administered $2 \mathrm{ml} / \mathrm{kg}$ body weight of vehicle through oral route. Group II received metformin $(150 \mathrm{mg} / \mathrm{kg}$ ). Group III to XIV received different extracts at doses of 100,200 , and $400 \mathrm{mg} / \mathrm{kg}$ in a similar manner. After 1, 2, 4, and $8 \mathrm{~h}$ interval of single-dose drug administration, the blood glucose levels were measured. The results were depicted in Table 1.

\section{Oral glucose tolerance test (OGTT) in rats}

The method of Dash et al., 2008, was followed [22]. Fasted rats were divided into fourteen groups of six rats each. Group I animals (solvent control) were administered $2 \mathrm{ml} / \mathrm{kg}$ body weight of vehicle through oral route. Group II received standard drug metformin $(150 \mathrm{mg} / \mathrm{kg})$. Group III to XIV received the test extract at doses of 100, 200, and $400 \mathrm{mg} / \mathrm{kg}$, respectively, through oral route. All the rats of different groups were administered orally glucose at a dose of $2 \mathrm{~g} / \mathrm{kg}$ body weight after $30 \mathrm{~min}$ of treatment. The blood glucose concentrations were determined $30,60,150$, and $180 \mathrm{~min}$ after the glucose loading (Table 2).

\section{Streptozotocin-induced hyperglycemic rats}

The method was performed as suggested by Dash et al., 2008 [22]. The tested animals were kept in standard environmental condition in the laboratory. The animals were fasted for $24 \mathrm{hr}$ but were allowed free access of water ad libitum Streptozotocin a dose of $65 \mathrm{mg} / \mathrm{kg}$ in normal saline was injected through intraperitaneal route. Standard laboratory diet ad libitum was provided to the experimental animals. Under the mild anesthetic condition, the blood was withdrawn from the tip of the tail of each rat, and the blood glucose level was checked before Streptozotocin-induced and $24 \mathrm{~h}$ after streptozotocinisation. To measure the blood glucose level above, the stated procedure was followed. Rats having the blood glucose level above $225 \mathrm{mg} / \mathrm{dl}$ [23] were selected for study and grouped into fourteen groups consisting of six animals each. This condition was observed at the end of $48 \mathrm{~h}$ after streptozotocinisation. Orally, vehicle ( $2 \mathrm{ml} / \mathrm{kg}$ p.o) was received by the Group I which served as diabetic control; metformin (150 mg/kg) was received by Group II; and petroleum ether,chloroform,ethanol and aqueous extract at dose of 100,200, and $400 \mathrm{mg} / \mathrm{kg}$ P.O, respectively were received by group III to group XIV. After 1, 2, 4, and $8 \mathrm{~h}$ interval of single-dose drug administration, the blood glucose levels were measured (Table 3).

\section{Statistical analysis}

All the values were expressed as mean \pm standard error of mean, for six animals in each group. The differences between groups were evaluated

Table 1: Effect of different extracts of the Acacia suma on the blood glucose level in normal rats

\begin{tabular}{|c|c|c|c|c|c|c|c|}
\hline \multirow[t]{3}{*}{ Group } & \multirow[t]{3}{*}{ Treatment } & \multirow[t]{3}{*}{ Dose (mg/kg) } & \multirow[t]{3}{*}{ Fasting } & \multicolumn{4}{|c|}{ Blood glucose concentration (mg/dl) (normoglycemic study) } \\
\hline & & & & \multicolumn{4}{|c|}{ Time (h) after treatment } \\
\hline & & & & 1 & 2 & 4 & 8 \\
\hline I & Control & $2 \mathrm{ml} / \mathrm{kg}$ & $97.63 \pm 2.48$ & $96.38 \pm 2.1$ & $98.16 \pm 2.25$ & $97.83 \pm 2.12$ & $98.66 \pm 2.49$ \\
\hline II & Metformin & $150 \mathrm{mg} / \mathrm{kg}$ & $97.72 \pm 2.59$ & $\begin{array}{l}87.25 \pm 2.20^{* *} \\
(10.71 \%)\end{array}$ & $\begin{array}{l}83.54 \pm 2.27^{* *} \\
(14.51 \%)\end{array}$ & $\begin{array}{l}76.36 \pm 3.62^{* *} \\
(21.85 \%)\end{array}$ & $\begin{array}{l}72.85 \pm 4.75^{* *} \\
(25.46 \%)\end{array}$ \\
\hline III & Petroleum ether & 100 & $104.56 \pm 3.44$ & $\begin{array}{l}103.72 \pm 8.05 \\
(0.80 \%)\end{array}$ & $\begin{array}{l}102.84 \pm 8.24 \\
(1.64 \%)\end{array}$ & $\begin{array}{l}102.10 \pm 9.64 \\
(2.35 \%)\end{array}$ & $\begin{array}{l}101.18 \pm 9.34 \\
(3.23 \%)\end{array}$ \\
\hline IV & & 200 & $106.75 \pm 2.59$ & $\begin{array}{l}105.31 \pm 8.44 \\
(1.34 \%)\end{array}$ & $\begin{array}{l}104.85 \pm 7.64 \\
(1.77 \%)\end{array}$ & $\begin{array}{l}103.68 \pm 10.20 \\
(2.87 \%)\end{array}$ & $\begin{array}{l}102.74 \pm 9.28 \\
(3.75 \%)\end{array}$ \\
\hline V & & 400 & $105.6 \pm 3.34$ & $\begin{array}{l}102.77 \pm 10.24 \\
(2.67 \%)\end{array}$ & $\begin{array}{l}101.65 \pm 9.48 \\
(3.74 \%)\end{array}$ & $\begin{array}{l}100.10 \pm 10.25 \\
(5.20 \%)\end{array}$ & $\begin{array}{l}98.13 \pm 10.26 \\
(7.07 \%)\end{array}$ \\
\hline VI & & 100 & $98.36 \pm 9.58$ & $\begin{array}{l}97.25 \pm 9 \\
(1.12 \%)\end{array}$ & $\begin{array}{l}96.32 \pm 9.38 \\
(2.07 \%)\end{array}$ & $\begin{array}{l}95.20 \pm 10.27 \\
(3.21 \%)\end{array}$ & $\begin{array}{l}94.98 \pm 11.63 \\
(3.40 \%)\end{array}$ \\
\hline VII & Chloroform & 200 & $96.33 \pm 7.28$ & $\begin{array}{l}94.87 \pm 8.73 \\
(1.51 \%)\end{array}$ & $\begin{array}{l}93.86 \pm 8.72 \\
(2.56 \%)\end{array}$ & $\begin{array}{l}93.00 \pm 10.22 \\
(3.45 \%)\end{array}$ & $\begin{array}{l}92.65 \pm 10.37 \\
(3.82 \%)\end{array}$ \\
\hline IX & Ethanol & 100 & $99.23 \pm 2.34$ & $\begin{array}{l}97.75 \pm 3.30 \\
(1.49 \%)\end{array}$ & $\begin{array}{l}96.92 \pm 2.53 \\
(2.23 \%)\end{array}$ & $\begin{array}{l}96.00 \pm 3.78 \\
(3.25 \%)\end{array}$ & $\begin{array}{l}95.55 \pm 3.44 \\
(3.7 \%)\end{array}$ \\
\hline $\mathrm{X}$ & & 200 & $99.37 \pm 2.22$ & $\begin{array}{l}97.65 \pm 2.14 \\
(1.73 \%)\end{array}$ & $\begin{array}{l}96.35 \pm 2.74 \\
(3.03 \%)\end{array}$ & $\begin{array}{l}95.25 \pm 4.75 \\
(4.14 \%)\end{array}$ & $\begin{array}{l}94.55 \pm 5.55^{*} \\
(4.85 \%)\end{array}$ \\
\hline XI & & 400 & $98.50 \pm 2.02$ & $\begin{array}{l}94.94 \pm 3.25 \\
(3.61 \%)\end{array}$ & $\begin{array}{l}91.00 \pm 5.82 * \\
(7.61 \%)\end{array}$ & $\begin{array}{l}89.10 \pm 3.50^{* *} \\
(9.54 \%)\end{array}$ & $\begin{array}{l}86.00 \pm 3.27^{* *} \\
(12.69 \%)\end{array}$ \\
\hline XII & Aqueous & 100 & $97.33 \pm 8.50$ & $\begin{array}{l}96.00 \pm 8.34 \\
(1.30 \%)\end{array}$ & $\begin{array}{l}95.00 \pm 8.23 \\
(2.39 \%)\end{array}$ & $\begin{array}{l}94.14 \pm 8.64 \\
(3.27 \%)\end{array}$ & $\begin{array}{l}93.75 \pm 6.28 \\
(3.52 \%)\end{array}$ \\
\hline XIII & & 200 & $97.73 \pm 9.58$ & $\begin{array}{l}96.26 \pm 7.25 \\
(1.50 \%)\end{array}$ & $\begin{array}{l}95.15 \pm 7.35 \\
(2.63 \%)\end{array}$ & $\begin{array}{l}94.50 \pm 7.41 \\
(3.32 \%)\end{array}$ & $\begin{array}{l}93.77 \pm 7.92 \\
(4.00 \%)\end{array}$ \\
\hline XIV & & 400 & $97.50 \pm 7.84$ & $\begin{array}{l}95.24 \pm 7.38 \\
(2.31 \%)\end{array}$ & $\begin{array}{l}94.00 \pm 8.55 \\
(3.58 \%)\end{array}$ & $\begin{array}{l}92.00 \pm 7.95 \\
(5.64 \%)\end{array}$ & $\begin{array}{l}90.25 \pm 7.43^{*} \\
(7.43 \%)\end{array}$ \\
\hline
\end{tabular}

Results expressed as mean \pm standard error of mean from six observations $(n=6) .{ }^{*} p<0.05$ and ${ }^{* *} \mathrm{p}<0.01$ as compared with the control group (one-way analysis of variance followed by Dunnett's t-test). Figures in parenthesis denote percentage reduction of blood glucose 
Table 2: Effect of different extracts of the Acacia suma oral glucose tolerance in normal rats

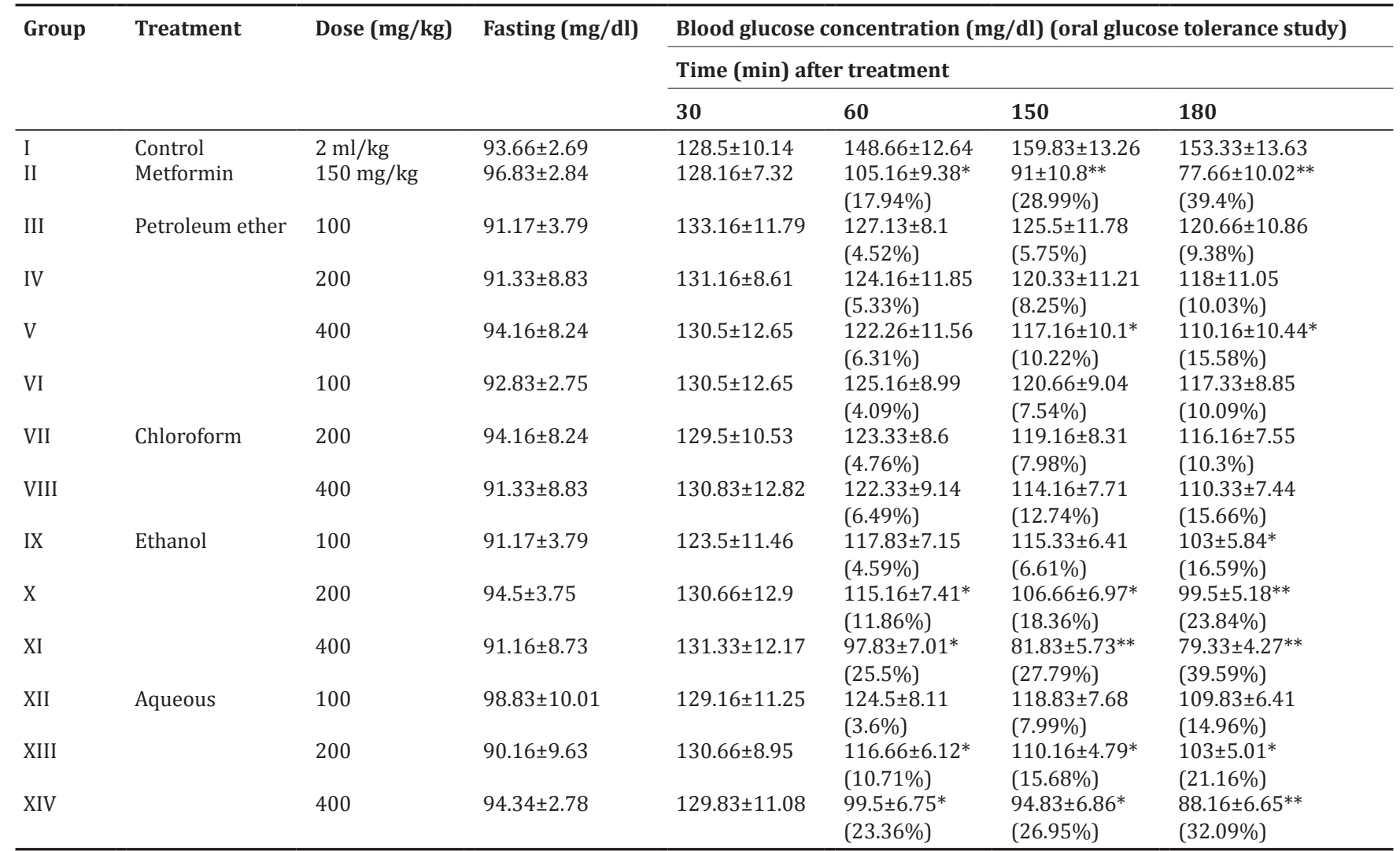

Results expressed as mean \pm standard error of mean from six observations $(\mathrm{n}=6) .{ }^{*} \mathrm{p}<0.05$ and ${ }^{* *} \mathrm{p}<0.01$ as compared with the control group (one-way analysis of variance followed by Dunnett's t-test). Figures in parenthesis denote percentage reduction of blood glucose

Table 3: Effect of different extracts of the Acacia suma on the blood glucose level in streptozotocin induces diabetic rats

\begin{tabular}{|c|c|c|c|c|c|c|c|}
\hline \multirow[t]{3}{*}{ Group } & \multirow[t]{3}{*}{ Treatment } & \multirow[t]{3}{*}{ Dose (mg/kg) } & \multirow[t]{3}{*}{ Fasting (mg/dl) } & \multicolumn{4}{|c|}{ Blood glucose concentration (mg/dl) (hypoglycemic study) } \\
\hline & & & & \multicolumn{4}{|c|}{ Time $(h)$ after treatment } \\
\hline & & & & 1 & 2 & 4 & 8 \\
\hline I & Control & $2 \mathrm{ml} / \mathrm{kg}$ & $239.33 \pm 2.2$ & $248.16 \pm 1.81$ & $250.5 \pm 2.71$ & $255.66 \pm 1.9$ & $258.83 \pm 2.12$ \\
\hline II & Metformin & $150 \mathrm{mg} / \mathrm{kg}$ & $240.16 \pm 10.2$ & $\begin{array}{l}201 \pm 10.11^{*} \\
(16.30 \%)\end{array}$ & $\begin{array}{l}155 \pm 14.88^{* *} \\
(35.45 \%)\end{array}$ & $\begin{array}{l}112.66 \pm 9.23^{* *} \\
(53.08 \%)\end{array}$ & $\begin{array}{l}88.33 \pm 9.93^{* *} \\
(63.22 \%)\end{array}$ \\
\hline III & Petroleum ether & 100 & $239.83 \pm 9.88$ & $\begin{array}{l}231.33 \pm 11.35 \\
(3.54 \%)\end{array}$ & $\begin{array}{l}226.83 \pm 12.33 \\
(5.42 \%)\end{array}$ & $\begin{array}{l}221.5 \pm 14.41 \\
(7.64 \%)\end{array}$ & $\begin{array}{l}217.5 \pm 10.83 \\
(9.31 \%)\end{array}$ \\
\hline IV & & 200 & $237.5 \pm 11.56$ & $\begin{array}{l}228.66 \pm 13.21 \\
(3.72 \%)\end{array}$ & $\begin{array}{l}223.33 \pm 14.1 \\
(5.96 \%)\end{array}$ & $\begin{array}{l}216 \pm 13.02 \\
(9.05 \%)\end{array}$ & $\begin{array}{l}211.66 \pm 13.68 \\
(10.88 \%)\end{array}$ \\
\hline V & & 400 & $235 \pm 12.2$ & $\begin{array}{l}224.66 \pm 14.46 \\
(4.4 \%)\end{array}$ & $\begin{array}{l}216.83 \pm 14.13 \\
(7.73 \%)\end{array}$ & $\begin{array}{l}207.33 \pm 15.86 \\
(11.77 \%)\end{array}$ & $\begin{array}{l}200.33 \pm 9.26 \\
(14.75 \%)\end{array}$ \\
\hline VI & & 100 & $242.83 \pm 2.21$ & $\begin{array}{l}238.33 \pm 11.44 \\
(1.64 \%)\end{array}$ & $\begin{array}{l}227.13 \pm 13.6 \\
(6.46 \%)\end{array}$ & $\begin{array}{l}228.5 \pm 15.36 \\
(5.90 \%)\end{array}$ & $\begin{array}{l}222 \pm 9.42^{*} \\
(8.57 \%)\end{array}$ \\
\hline VII & Chloroform & 200 & $238.5 \pm 2.01$ & $\begin{array}{l}232.13 \pm 13.47 \\
(2.67 \%)\end{array}$ & $\begin{array}{l}225.33 \pm 13.12 \\
(5.52 \%)\end{array}$ & $\begin{array}{l}219.83 \pm 13.75 \\
(7.82 \%)\end{array}$ & $\begin{array}{l}213.33 \pm 14.24^{*} \\
(10.55 \%)\end{array}$ \\
\hline IX & Ethanol & 100 & $236.83 \pm 13.11$ & $\begin{array}{l}227.16 \pm 14.22 \\
(4.08 \%)\end{array}$ & $\begin{array}{l}212.5 \pm 9.66^{*} \\
(10.27 \%)\end{array}$ & $\begin{array}{l}207.83 \pm 9.65^{*} \\
(12.24 \%)\end{array}$ & $\begin{array}{l}199.83 \pm 11.1^{*} \\
(15.62 \%)\end{array}$ \\
\hline $\mathrm{X}$ & & 200 & $234.83 \pm 14.62$ & $\begin{array}{l}211.66 \pm 9.59 * \\
(9.86 \%)\end{array}$ & $\begin{array}{l}190 \pm 16.01 * \\
(19.09 \%)\end{array}$ & $\begin{array}{l}182 \pm 16.01 * \\
(22.49 \%)\end{array}$ & $\begin{array}{l}143.83 \pm 6.05^{* *} \\
(38.75 \%)\end{array}$ \\
\hline XI & & 400 & $235.5 \pm 23.13$ & $\begin{array}{l}197.5 \pm 10.68^{*} \\
(17.05 \%)\end{array}$ & $\begin{array}{l}166.66 \pm 14^{* *} \\
(29.23 \%)\end{array}$ & $\begin{array}{l}132.16 \pm 8.89 * * \\
(43.88 \%)\end{array}$ & $\begin{array}{l}98 \pm 9.85^{* *} \\
(58.38 \%)\end{array}$ \\
\hline XII & Aqueous & 100 & $238.66 \pm 10.05$ & $\begin{array}{l}235.66 \pm 11.89 \\
(1.25 \%)\end{array}$ & $\begin{array}{l}229.5 \pm 12.93 \\
(3.83 \%)\end{array}$ & $\begin{array}{l}206.83 \pm 12.1^{*} \\
(13.33 \%)\end{array}$ & $\begin{array}{l}202.66 \pm 13.68^{*} \\
(15.08 \%)\end{array}$ \\
\hline XIII & & 200 & $236.83 \pm 11.33$ & $\begin{array}{l}227.33 \pm 7.4 \\
(4.01 \%)\end{array}$ & $\begin{array}{l}199.66 \pm 12.3^{*} \\
(15.69 \%)\end{array}$ & $\begin{array}{l}198.5 \pm 12.27 * \\
(16.18 \%)\end{array}$ & $\begin{array}{l}190.16 \pm 15.64^{*} \\
(19.7 \%)\end{array}$ \\
\hline XIV & & 400 & $236.33 \pm 15.65$ & $\begin{array}{l}199.16 \pm 14.37 * \\
(15.72 \%)\end{array}$ & $\begin{array}{l}194.5 \pm 14.59 * \\
(17.69 \%)\end{array}$ & $\begin{array}{l}188.16 \pm 14.59 * \\
(20.38 \%)\end{array}$ & $\begin{array}{l}156.16 \pm 16.41^{* *} \\
(33.92 \%)\end{array}$ \\
\hline
\end{tabular}

Results expressed as mean \pm standard error of mean from six observations $(\mathrm{n}=6) .{ }^{*} \mathrm{p}<0.05$ and ${ }^{* *} \mathrm{p}<0.01$ as compared with the control group (one-way analysis of variance followed by Dunnett's t-test). Figures in parenthesis denote percentage reduction of blood glucose 
by one-way analysis of variance followed by Dunnett's Multiple Comparison test. $\mathrm{p}<0.05$ was considered statistically significant.

\section{RESULTS}

\section{Using normoglycemic rats}

Results obtained from Table 1 of the normoglycemic study expressed that test extracts showed a significant reduction of blood glucose concentration which was in a dose-dependent manner and compares with the control. It was observed that ethanol extract reduced $12.69 \%$ blood glucose levels at $400 \mathrm{mg} / \mathrm{kg}$, p.o., whereas metformin $(150 \mathrm{mg} / \mathrm{kg}$, p.o) showed $25.46 \%$ in rats after $8 \mathrm{~h}$ treatment.

\section{OGTT in rats}

The effect of test extracts on glucose tolerance test in normal rats is shown in Table 2. The peak of blood glucose level was increased rapidly from the fasting blood glucose value and after that subsequently decreased after $30 \mathrm{~min}$ of glucose administration through the oral route. All the tested extracts $(100,200$, and $400 \mathrm{mg} / \mathrm{kg}$, p.o.) exhibited significant hypoglycemic effect, but metformin and ethanol (200 and $400 \mathrm{mg} / \mathrm{kg}$ ) extract significantly depressed the peak of blood glucose level at $60 \mathrm{~min}$ after glucose loading.

\section{Streptozotocin-induced hyperglycemic rats}

In an antihyperglycemic study (Table 3), the rise in the blood glucose level was observed after $24 \mathrm{~h}$ of streptozotocinisation to the animals. Single administration $(100,200$, and $400 \mathrm{mg} / \mathrm{kg}$, p.o.) of the ethanol and aqueous extracts of root of $A$. suma in diabetic rats showed significant reduction in blood glucose level, whereas ethanol extract $(400 \mathrm{mg} / \mathrm{kg}$ ) was found maximum reduction in blood glucose level (58.38\%) at the end of $8 \mathrm{~h}$. The results of the ethanol extract are comparable to that of the reference standard metformin.

\section{DISCUSSION}

From ancient times, the physicians and laymen were used various active principals obtained from the traditional medicinal plants to treat a large variety of human diseases such as diabetes, cancer, and coronary heart diseases. Beneficial multiple activities such as manipulating carbohydrate metabolism by various mechanisms, preventing and restoring the integrity and function of beta-cells, releasing insulin activity, improving glucose uptake and utilization, and the antioxidant properties present in medicinal plants offer an exciting opportunity to develop them into novel therapeutics [24]. The antihyperglycemic activity of $A$. suma extract may be due to the presence of several bioactive antidiabetic principles.

Streptozotocin can irreversibly damage beta-cell DNA. Administration of streptozotocin caused rapid destruction of pancreatic beta-cells in rats, which led to impaired glucose-stimulated insulin release and insulin resistance, both of which are marked feature of Type II diabetes. The hypoglycemic effect of plant extract is generally dependent on the degree of pancreatic beta-cell destruction and useful in moderate streptozotocin-induced diabetes. The lesser the degree of pancreatic beta-cell destruction, the more useful the herb is in treating diabetes in animals [25].

The glucose and methylnitrosourea moieties are formed from streptozotocin. Due to its alkylating properties, the fragment of DNA, biological macromolecules, and beta-cells are destroyed and produce insulin-dependent diabetes. The targeting of mitochondrial DNA, thereby impairing the signaling function of beta-cell mitochondrial metabolism, also explains how streptozotocin can inhibit glucoseinduced insulin secretion [26].

The biologically active ingredients that present in the extracts are responsible to reduce the blood sugar which is unknown at present. There is ongoing research to isolate and characterize the bioactive compound(s) responsible for the antidiabetic activity of $A$. suma.

\section{CONCLUSION}

From the present study, it is apparent that the roots of $A$. suma possess the hypoglycemic activity and it justifies the use of the roots of the plant for treating diabetes as suggested in the folklore remedies.

\section{ACKNOWLEDGMENT}

The authors are thankful for the principal, Institute of Pharmacy and Technology, Salipur, Cuttack, Odisha, India, for encouragement to carry out this study.

\section{AUTHORS' CONTRIBUTION}

Jitendra Debata: All fieldwork, laboratory experiments, preparation, and correction of the manuscript. H. K. Sundeep Kumar: Supervision of experiments.

\section{CONFLICTS OF INTEREST}

We the authors announced that we have no conflicts of interest.

\section{REFERENCES}

1. O'Keefe JH, Bell DS, Wyne KL, Haffner SM. Overview of Diabetes Mellitus, Diabetes Essentials. $2^{\text {nd }}$ ed. New Delhi: Jaypee Brothers Medical Publisher Pvt. Ltd.; 2006.

2. Gupta A, Gupta V. Diabetic blindness: A major challenge J Indian Med Assoc 2000;98:772-5.

3. Chattopadhyay RR, Medha C, Das S, Basu TK. Hypoglycemic and antihyperglycemic effect of Gymnema sylvestre leaf extract in rats. Fitoterapia 1993;15:450-4.

4. Zhang X. Introduction WHO Monographs on Selected Medicinal Plants. $1^{\text {st }}$ ed. Vol. 1. New Delhi: A.I.T.B.S. Publishers; 2005.

5. Kiritikar KR, Basu BD. Indian Medicinal Plants. Vol. 2. Allahabad: Lalit Mohan Basu; 1933. p. 935.

6. Anonymous. The Wealth of India. Vol. 1. New Delhi: CSIR; 1985. p. 42.

7. Vanpuyvelde L, Geysen D, Ayobangira FX, Hakizamunge E, Nshimiyimana A, Kalisa A. Screening for Asthma. J. Ecthnopharmacol 1985;13:209-15.

8. Headbarg O, Headberg PJ, Madati NK, Mshigeni EN, Mshiu GS. Inventory of plants used in traditional medicine in Tanzania. II. Plants of the families Dilleniaceae Opiliaceae. J. Ecthnopharmacol 1983;9:105-27.

9. Almagboul AZ, Bashir AK, Karim A, Salim M, Farouk A, Khalid SA. Antimicrobial activity of certain Sudanese plants used in folkloric medicine: Screening for antibacterial activity. Fitoterapia 1988;59:393-6.

10. Selvanayahgam ZE, Gnanevendhan SG, Balakrishna K, Rao RB. Antisnake venom botanicals from ethnomedicine. J. Herbs Spices Med Plants 1994;2:45-100.

11. Gessler MC, Nkunya MH, Mwasumbi LB, Heinrich M, Tanner M. Screening Tanzanian medicinal plants for antimalarial activity. Acta Trop 1994;56:65-77.

12. Watt JM, Breyer-Brandwijk MG. The Medicinal and Poisonous Plants of Southern and Eastern Africa. E+S. London: Livingstone Ltd.; 1962. p. 1455-7.

13. Massie Y, Nshimo CM. Screening for Abscesses and Sores.. East Afr Med J 1995;72:661-3.

14. Gandhi P. New proanthocyanidin from the stem bark of Acacia suma. Experientia 1977;33:1272.

15. Rastogi RP, Mehrotra BN. Compendium of Indian Medicinal Plants. Vol. 2. New Delhi: Central Drug Research Institute, Lucknow and Publications, and Information Directorate; 1933. p. 4-5.

16. Ayoub SM. Flavenol molluscicides from the Sudan Acacias. Int J Crude Drug Res 1985;23:87-90.

17. Acharyya S, Dash GK, Mondal S, Acharyya A, Dash SK. Studies on the hypoglycaemic activity of Acacia suma (Roxb.) barks. Int J Chem Anal Sci 2010;1:10-3

18. Anonymous. Reviews on Indian Medicinal Plants. Vol. 1. New Delhi: ICMRV; 1963. p. 61.

19. Anonymous. OECD Guidelines for the Testing of Chemicals, Revised Draft Guidelines 423: Acute Oral Toxicity-Acute Toxic Class Method, Revised Document. Govt. of India: CPCSEA, Ministry of Social Justice and Empowerment; 2000.

20. Ganapaty S, Dash GK, Subburaju T, Suresh P. Diuretic, laxative 
and toxicity studies of Cocculus hirsutus aerial parts. Fitoterapia 2002;73:28-31.

21. Shivhare Y, Dangi S, Soni P, Singh P, Baghel SS. Acute toxicity study of aqueous extract of Coccinia indica (Roots). Asian J Res Pharm Sci 2011;1:23-5

22. Dash GK, Bal SK, Annapurna MM, Suresh P. Studies on the hypoglycaemic activity of Hemidesmus indicus R. Br. Roots. Pharmacogn Mag 2008;4:221-5.

23. Edwin E, Sheeja E, Dhanabal SP, Suresh B. Antihyperglycemic activity of Passiflora mollissima Bailey. Indian J Pharm Sci 2007;69:570-1.

24. Tiwari AK, Rao M. Diabetes mellitus and multiple therapeutic approaches of phytochemicals, present status, and future prospects. Curr Sci 2002;83:30-8.

25. Fischer LJ, Hamburger SA. Inhibition of alloxan action in isolated pancreatic islets by superoxide dismutase, catalase, and a metal chelator. Diabetes 1980;29:213-6.

26. Lenzen S. The mechanisms of alloxan and streptozotocin-induced diabetes. Diabetologia 2008;51:216-26. 